\title{
Acceptance of e-learning technology by Saudi Arabian students in Taibah University, based on Technology Acceptance Model
}

\section{Talal bin Hasan Hamza kabili}

Taibah university Al Madinah Al mounawra Saudi Arabia

\section{Abstract:}

This research paper aim to study the acceptance of the e-learning technology by Saudi Arabian Students through a study with a sample of 120 students from Taibah University. The kingdom of Saudi Arabia has Launched the e-learning at the national center of e-learning, and has created a structure to manage this new way of teaching and learning in majority of universities in Saudi Arabia with creation of the deanship of e-learning in each university. The introduction of this new technology of teaching and learning for students promotes the technological learning system in Saudi Arabia, for professors and for the institutions and for all actors of online education. The introduction of the innovation in Saudi Arabian learning system motivated us to ask the question: Does this new system, regarded innovation as it is year defined from Rogers (1995), Can Be Accepted by students? The Technology Acceptance Model (TAM) developed by Davis (1989) is one of the Most Important models to explain innovation adoptions. Explains the adoption of this model by two factors: the Perceived Usefulness of the system (PU) and Its Perceived Ease of Use (PEU).

Key Words: e-learning, TAM, perception, usefulness, ease of use.

\section{Introduction}

For various reasons (economic, educational,...), Distance Education was launched in the Kingdom of Saudi Arabia through the creation of national center of e-learning, an institution in charge of management of new teaching and learning technology in collaboration with deanships of e-learning in each university at the kingdom of Saudi Arabia. The e-learning technology is the use of new technologies in teaching and learning, therefore, as an innovation, the latter being defined as any idea, technology, practice or object perceived as new in teaching and learning by an individual (Rogers, 1995). This is of little importance that the idea is objectively new or not relative to the time elapsed since its first use or discovery (Rogers, 1995; Tabak and Barr, 1999). 
Teachers and students, as the main actors of the e-learning system, found themselves confronted with a system which they had little or no preparation. Therefore, the question of acceptance of this innovation, especially for students who are end users of the system. Ezzina and Selmi (2004) studied the acceptance of distance education by students. They showed a rather negative perception of the system. However, the novelty of using this system could be the cause of this perception. Indeed, the introduction of any innovation is accompanied by resistance from users who may be stronger or weaker depending on the degree of novelty introduced by the system. It is, therefore, necessary to conduct a study to perceive the evolution of perception.

\section{Theory}

The Technology Acceptance Model (TAM) developed by Davis (1989) studies the adoption in terms of perceived ease of use and perceived usefulness based on behavioral intentions and beliefs system (Harker and Van Akkeren, 2002). In this model, the Perceived Usefulness (PU) and Perceived Ease of Use (PFU) are influences on development of a particular attitude towards the use of innovations (Davis and al., 1989). This reflects the favorable or unfavorable feelings toward the use of the system. The Perceived Usefulness is defined as "the degree to which a person believes that using a particular system would enhance his job performance." The Perceived Usability is defined as "the degree to which a person believes that using a particular system will be free of effort" (Davis, 1989). According to Davis and al. (1989), all other factors are not explicitly included in the model are assumed to influence intentions and usage through ease of use and usefulness. The Model of Technology Acceptance of Davis (1989) has undergone several extensions by the integration of other external variables including (Davis, Bagozzi et al., 1989; Dishaw and Strong 1999; Karahanna and Straub , 1999 cited in Ben Zakour, 2002). 


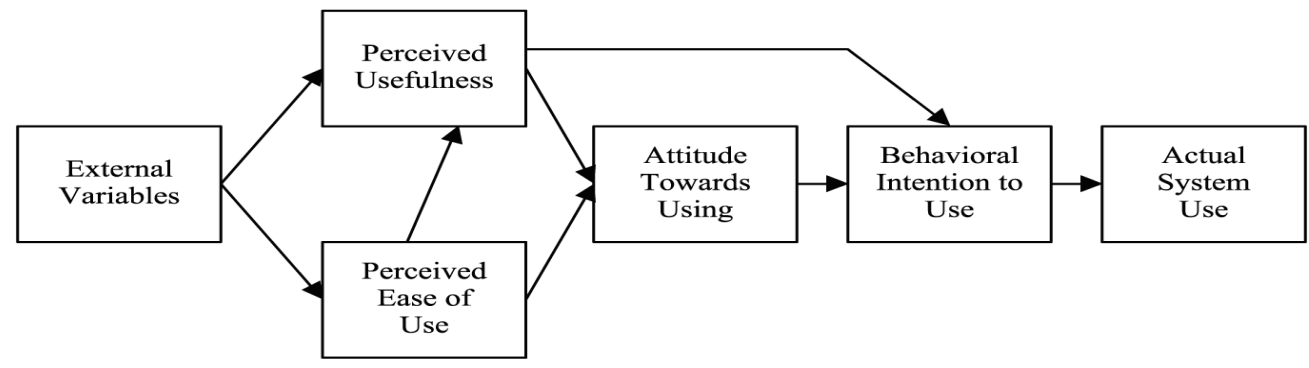

Fig. 1 Technology acceptance model: source (Davis, 1989)

In this work, we seek to determine the degree of acceptance of e-learning by Saudi Arabian students.

- The perceived usefulness influence, positively, accepting of the elearning technology : If the system of distance education is seen by students as helpful to the learning operation, it will be favorably received.

- The perceived ease of use influence, positively, the acceptance of the e-learning:

More e-learning system are perceived as easy to learn and use, more students will be ready to adopt.

- The weather influence, positively, the acceptance of distance education: More students are in contact with the e-learning system, the students are willing to adopt it.

The ease of use of a technology by students based on the computer:

In our study, The adoption of a technology by students based on the computer and learning technologies from Davis point of view is explained by the perceived ease of use of platform functionalities. According to this model, the perceived ease of use is determinant of developing a particular attitude towards the use of innovation (Davis 1989).

The perceived usefulness of e-learning system:

In our study, the adoption of a technology by students based on the computer and learning technologies from Davis point of view is explained by the perceived usefulness of elearning system. According to this model, the perceived usefulness is determinant of developing a particular attitude towards the use of innovation (Davis 1989). 


\section{Research Questions}

Two hypotheses will be tested:

Hypothesis 1: The perceived usefulness of the e-learning innovation has a positive impact on the acceptance of learning by our students.

Hypothesis 2: The perceived ease of use of the e-learning innovation has a positive impact on the acceptance of learning by our students.

\section{Method}

\section{bjectives of the study}

The main objective of our study is to define the degree of acceptance of the e-learning innovation by students in Taibah University, explained by the ease of use of the innovation and the usefulness of this e-learning innovation.

\section{Research methodology}

degree of acceptance of the e-learning innovation by students in Taibah University, explained by the ease of use of the innovation and the usefulness of this e-learning innovationhe questionnaire method is the support of our study that was distributed face to face. his questionnaire contains 8 questions which can explore the degree of the acceptance of the e-learning innovation by students in Taibah university.

\section{Statistical Package for the Social Sciences}

\section{Results and data analysis}

Table 2 Results of the questionnaire

\begin{tabular}{|l|c|c|}
\hline \multicolumn{3}{|c|}{ The ease of the use of the e-learning system } \\
\hline Variable & $\begin{array}{c}\text { Positive } \\
\text { perception }\end{array}$ & $\begin{array}{l}\text { Negative } \\
\text { perception }\end{array}$ \\
\hline The ease of learning & 25.9 & 74,1 \\
\hline The ease of answer of needs & 38.9 & 45.1 \\
\hline Comprehension & 43,7 & 56.3 \\
\hline Flexibility & 52,1 & 47.9 \\
\hline $\begin{array}{l}\text { Acquire high competence in using } \\
\text { e-learning system }\end{array}$ & 35.5 & 64.5 \\
\hline \multicolumn{2}{|c|}{ The usefulness of e-learning } \\
\hline Improvement of the learning & 55.5 & 45.5 \\
\hline $\begin{array}{l}\text { Improvement of the performance } \\
\text { in the learning }\end{array}$ & 48.3 & 40.7 \\
\hline $\begin{array}{l}\text { Improvement of the efficiency of } \\
\text { learning }\end{array}$ & 42.1 & 57.9 \\
\hline
\end{tabular}




\section{Discussions}

\section{The ease of the use of the e-learning system}

\section{Ease of learning}

The negative perception for variable "The ease of learning" is always dominant $74,1 \%$ compared to students having a positive perception about the ease of learning at Jusur e-learning platform. A majority of students believe that the elearning system presenting the learning process isn't easy to use. The passage in the new platform could explain to a certain extent, this observation. This first result explains why students of the sample don't adopt e-learning. Based on Davis model the adoption of the e-learning technology is is explained by the perceived ease of use of platform functionalities. According to this model, the perceived ease of use is determinant of developing a particular attitude towards the use of innovation (Davis 1989).

\section{Ease of answer to needs}

The negative perception for variable " Ease of answer of needs " is always dominant $45.1 \%$ compared to students having a positive perception $38.9 \%$ about Ease of answer of needs in the e-learning process at Jusur e-learning platform. An important percentage of students believe that the needs of students at the e-learning process are satisfied an hence this second result explains why students of the sample don't adopt e-learning. Based on Davis model the adoption of the elearning technology is explained by the perceived ease of use of Jusur e-learning platform functionalities. The perceived ease of use of the e-learning system by students explained by the ease of answer of needs at the e-learning process, is determinant of developing a particular attitude towards the use of innovation (Davis 1989).

\section{Comprehension:}

The result shows clearly that a majority of learners $56,3 \%$ have a negative perception about the comprehension of the learning resource at the e-learning system compared to a group of $43,7 \%$ of learners having a positive perception about 
the comprehension of the learning resources. This result is also important to evaluate the degree of adoption of the elearning innovation by learners in Taibah university. Understanding learning resource is determinant of the ease of learning system, Based on Davis models the perceived ease of use is determinant of developing a particular attitude towards the use of innovation (Davis 1989).

\section{Flexibility:}

$52,1 \%$ of students of the sample have a positive perception about the variable "flexibility of learning process" and $47,9 \%$ of students of the sample believe have a negative perception about this variable. This sub determinant of the ease of learning in our case isn't determinative for the adoption of e-learning technology by students in Taibah university because results of negative and positive perception are approximately equal.

\section{Acquire high competence in using e-learning system:}

$52,1 \%$ of students of the sample have a positive perception about the variable flexibility of learning process and $47,9 \%$ of students of the sample believe have a negative perception about the flexibility of the learning process. This sub determinant of the ease of learning in our case isn't determinative for the adoption of e-learning technology by students in Taibah university because results of negative and positive perception are approximately equal.

\section{The usefulness of e-learning}

Improvement of the learning:

The results of the survey shows clearly that $55,5 \%$ of students have a positive perception about the improvement of the e-learning and 44,5\% of student of the sample have a negative perception about the improvement of the e-learning. This sub determinant that is "the Improvement of the learning $"$ in our case is determinative for the adoption of learning technology by students in Taibah university because results positive perception are higher than results of negative 
perception for the improvement of the e-learning ( 55,5\% and $44,5 \%)$.

Improvement of the performance in the learning:

The results of the survey shows clearly that $48.3 \%$ of students have a positive perception about the improvement of the performance in the learning and $40.7 \%$ of student of the sample have a negative perception about this variable. This sub determinant that is "Improvement of the performance in the learning " in our case is determinative for the adoption of e-learning technology by students in Taibah university.

\section{Improvement of the efficiency of learning}

The Improvement of the efficiency of learning is a sub variable determinant of The usefulness of e-learning. The results of the survey show clearly that $42.1 \%$ of students of the sample have a positive perception about the improvement of the performance in the learning and $57.9 \%$ of student of the sample have a negative perception about this variable. This sub determinant "Improvement of the efficiency of learning" in our case is determinative for the adoption of e-learning technology by students in Taibah university, a majority of students have a negative perception about the improvement of the efficiency of learning.

\section{Conclusion and implications}

The introduction of the learning technology in Taibah university, which can be considered in launch phase suffers from a negative perception from learners point of views on behalf of the students. Indeed, a majority of students of the sample believe that the system is not easy to the use and that it is not useful for them in their studies. Several factors could explain this established fact:

The students do not feel the interest for them to adopt this new mode of learning no awareness campaign and no steady effort of communication was made and is made to promote the e-learning technology in Taiabh university at the level of establishments.

The training which the students receive is, probably, short to introduce for them the usefulness of the e-learning technology and its.The students who have more difficulties using the e-learning system. The 
students don't access frequently to the e-learning platform and to use the learning process inserted by teachers for learning and the time of access to the e-learning platform is insufficient to allow students to assimilate the e-learning resources.

\section{References}

Ben Zakour, A., (2002). Cultural aspects of the implementation of information technology and communication .. http://www.enssib.fr/gdr/pdf/doctorants/2 002-10 benzakou.pdf.

Davis, F. D., Bagozzi, R. P. and Warshaw, P. R., (1989). User Acceptance of Computer Technology: A Comparison of Two Theoretical Models. Management Science, 35 , August

Davis, F. D., Bagozzi, R. P. and Warshaw, P. R., (1989). User Acceptance of Computer Technology: A Comparison of Two Theoretical Models. Management

Science,

35 ,

August

8.

Davis, F. D., (1989). Perceived Usefulness, Perceived ease of use and user acceptance of information technology. MIS Quarterly, Vol. 13, No. 3,September.

Dhishaw, M. T. and Strong, D. M., (1997). Extending the technology acceptance model. Association for Information Systems 1997 Americas Conference Indianapolis, Indiana, August, 15-17.

Ezzina, R. and Selmi, S., (2004). The acceptance of the EAD by Tunisian students: Model Approach to Technology Acceptance (TAM). International Conference: ICT Mediterranean 2004 - Nice, November 26-27.

Harker, D. and Van Akkeren, J., (2002). Mobile Data Technologies and SME Adoption and Diffusion: An Empirical Study on Barriers and Facilitators. The Australian Journal of Information Systems, SJIA Editions - Vol 9 No 2, May. 